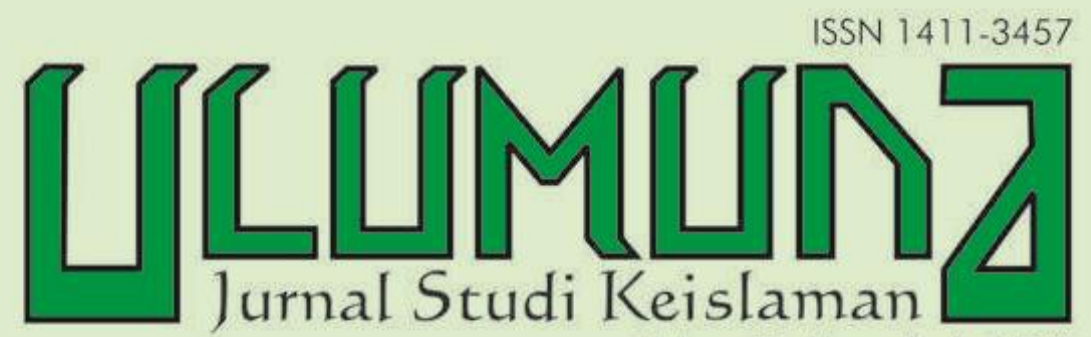

Volume $17 \cdot$ Nomor $1 \cdot$ Juni 2013

TERAKREDITASI B: SK Dirjen Dikti Kemdikbud Nomor: 56/DIKTI/Kep/2012, Tanggal 24 Juli 2012

MENCERNA AKAR FILSAFAT DALAM ISLAM Ismail Fahmi Arrauf PERKEMBANGAN PARADIGMA EPISTEMOLOGI DALAM FILSAFAT ISLAM Fathul Mufid EPISTEMOLOGI ISLAM: KEDUDUKAN WAHYU SEBAGAI SUMBER ILMU Anwar Muiahidin DARI ISLAMISASI ILMU MENUJU PENGILMUAN ISLAM: MELAWAN HEGEMONI EPISTEMOLOGI BARAT Ismail Toib dan Mukhlis INDUKTIVISME SEBAGAI BASIS PENGEMBANGAN ILMU PENGETAHUAN DALAM ISLAM Masdar Hilmy

PERTAUTAN ONTOLOGI FILSAFAT DAN TASAWUF: PERSPEKTIF TENTANG RELASI TUHAN, MANUSIA, DAN ALAM Hadarah Rajab PERTAUTAN EPISTEMOLOGI FILSAFAT DAN TASAWUF: TELAAH SISTEM PEMIKIRAN ABDUL HALIM MAHMUD Lalu Muchsin Effendi ETIKA DALAM FILSAFAT ISLAN:

PEMIKIRAN FILOSOF MUSLIM TENTANG KEBAHAGIAAN Mustain PEngembangan Sumber Daya MANusia DALAM PERSPEKTIF EPESTIMOLOGI FILSAFAT ISLAM Asep Kumiawan 


\section{DAFTAR ISI}

\section{Pedoman Transliterasi}

1-18 • Ismail Fahmi Arrauf,

"Mencerna Akar Filsafat dalam Islam"

19-40 • Fathul Mufid,

"Perkembangan Paradigma Epistemologi

dalam Filsafat Islam"

41-64 • Anwar Mujahidin

"Epistemologi Islam:

Kedudukan Wahyu Sebagai Sumber Ilmu"

65-96 • Ismail Toib dan Mukhlis

"Dari Islamisasi Ilmu Menuju Pengilmuan Islam:

Melawan Hegemoni Epistemologi Barat"

97-126 • Masdar Hilmy

"Induktivisme Sebagai Basis Pengembangan

Ilmu Pengetahuan dalam Islam"

127-152 • Hadarah Rajab

"Pertautan Ontologi Filsafat dan Tasawuf:

Telaah Relasi Tuhan, Manusia, dan Alam"

153-190 • Lalu Muchsin Effendi

"Pertautan Epistemologi Filsafat dan Tasawuf:

Telaah Sistem Pemikiran Abdul Halim Mahmud"

191-212• Mustain

"Etika dan Ajaran Moral Filsafat Islam:

Pemikiran Para Filosof Muslim tentang Kebahagiaan"

\section{3-230 • Asep Kurniawan}

Pengembangan Sumber Daya Manusia

dalam Perspektif Epestimologi Filsafat Islam

\section{APENDIKS}




\section{PEDOMAN TRANSLITERASI}

\begin{tabular}{|c|c|c|c|c|c|c|}
\hline 1 & $=$ & $\mathbf{a}$ & $\dot{\varepsilon}$ & $\dot{\varepsilon}$ & $=$ & $\mathrm{g}$ \\
\hline ب & $=$ & $\mathbf{b}$ & & ف & $=$ & $\mathbf{f}$ \\
\hline$ت$ & $=$ & $t$ & & ق & $=$ & $q$ \\
\hline$\dot{H}$ & $=$ & th & & ك5 & $=$ & $\mathbf{k}$ \\
\hline ج & $=$ & $\mathfrak{j}$ & & j & $=$ & 1 \\
\hline$\tau$ & $=$ & ḥ & & b & $=$ & $\mathbf{m}$ \\
\hline$\dot{\tau}$ & $=$ & $\mathbf{k h}$ & & ن & $=$ & $\mathbf{n}$ \\
\hline د & $=$ & d & & و & $=$ & $\mathbf{w}$ \\
\hline$\dot{j}$ & $=$ & dh & $\circ$ & ○ & $=$ & $\mathbf{h}$ \\
\hline$\jmath$ & $=$ & $\mathbf{r}$ & & $\varepsilon$ & $=$ & , \\
\hline j & $=$ & $\mathbf{z}$ & & ي & $=$ & $\mathbf{y}$ \\
\hline س & $=$ & $\mathrm{s}$ & & & & \\
\hline 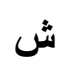 & $=$ & sh & \multicolumn{4}{|c|}{ Untuk Madd dan Diftong } \\
\hline ص - ص & $=$ & ș & i & $=$ & \multicolumn{2}{|c|}{$\bar{a}$ (a panjang) } \\
\hline ض & $=$ & d & إي اي & $=$ & \multicolumn{2}{|c|}{$\overline{1}$ (i panjang) } \\
\hline$b$ & $=$ & $\mathrm{t}$ & أو - & $=$ & \multicolumn{2}{|c|}{$\overline{\mathrm{u}}$ (u panjang) } \\
\hline ظ & $=$ & $\mathrm{z}$ & او - او & $=$ & \multicolumn{2}{|c|}{ aw } \\
\hline$\varepsilon$ & $=$ & 6 & أي & $=$ & \multicolumn{2}{|l|}{ ay } \\
\hline
\end{tabular}

Contoh penulisan dengan transliterasi:

اعوذ بالله من الشيطان الرجيم (a'üdhu bi al-Lāh min al-shaytān al-rajim);

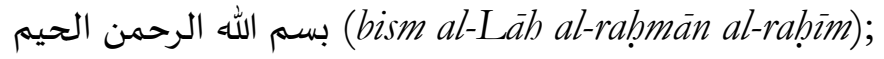

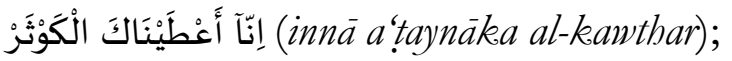

(fasalli lirabbika wanhar);

صباح الخير (șabāh al-khayr). 


\title{
EPISTEMOLOGI ISLAM: \\ KEDUDUKAN WAHYU SEBAGAI SUMBER ILMU
}

\author{
Anwar Mujahidin \\ (Fakultas Ushuluddin STAIN Ponorogo, Jatim \\ Email: pranotogomo@yahoo.com)
}

Abstract: Modern science dominated by idealism, rationalism, and empiricism has brought an acute humanity crisis. At the epistemology level, religion provides knowledge which guarantees human values, beyond ration and empirical findings. This paper aims at exploring texts of al-Qur'an as a source of knowledge. The methodology construction starts from seeing it as a paradigm-placing the boly text as an open corpus critically analyzed from linguistics, literary, and historical points of views.

Abstrak: Sains modern yang dikuasai oleh idealisme, rasionalisme dan empirisme telah membawa krisis kemanusiaan yang akut. Pada ranah epistemologis, agama menyediakan pengetahuan yang tidak disediakan oleh rasio maupun temuan empirik yang menjamin adanya nilai-nilai kemanusiaan. Paper ini bertujuan mengeksplorasi peluang dijadikannya wabyu al-Qur'an sebagai sumber ilmu. Konstruksi metodologi ilmiah dimulai dengan mengubah cara pandang terhadap wahyu al-Qur'an sebagai paradigma yang berarti menempatkan al-Qur'an dalam bakekat ontologisnya sebagai teks kebahasaan yang terbuka terbadap kerangka analisis modern seperti lingusitik, kritik sastra dan analisis historis. Hasil penelitian menunjukkan bahwa teks suci al-Qur'an yang bersumber dari wabyu dapat dijadikan sumber ilmu dengan persyaratan kajian dengan metodologi yang ilmiah.

Keywords: studi al-Qur'an, epistemologi, sumber ilmu, metodologi tafsir. 
EPISTEMOLOGI adalah salah satu cabang filsafat yang membahas tentang hakikat pengetahuan manusia. Persoalan pokok yang berkembang dalam epistemologi adalah meliputi sumber-sumber pengetahuan, watak dari pengetahuan manusia, apakah pengetahuan itu benar (valid) ataukah tidak. Bagaimana pengetahuan manusia itu didapat, dengan cara apa dan apa saja syarat-syarat yang harus dipenuhi. Sehingga epistemologi sampai pada problem hubungan metodologi dengan obyek dari ilmu pengetahuan. ${ }^{1}$

Dalam lingkungan studi Islam, istilah epistemologi sering dipertukarkan dengan istilah pemikiran. Pemikiran berasal dari kata pikir yang berarti akal budi, ingatan, angan-angan, sehingga pemikiran berarti proses, cara, perbuatan memikir. Dalam Kamus Besar Ilmu Pengetahuan, pikiran berarti suatu entitas yang memperlihatkan fungsi-fungsi seperti mencerap, mengamati, mengingat memungkinkan manusia merefleksikan dunia obyektif ke dalam tataran konsep, putusan dan teori lewat proses abstraksi, analisis, sintesis, pemecahan dan hipotesis. ${ }^{2}$ Menurut Michel Foucault, sebagaimana dikutip Johan Meuleman dalam kata pengantar penebitan karya Arkoun, pemikiran berarti pemahaman dan pandangan seseorang terhadap suatu objek (kenyataan). Pemahaman tersebut meliputi apa yang dianggap penting dan tidak penting, hubungan apa yang diadakan antara berbagai unsur kenyataan dalam penggolongan dan analisis, dan lain sejenisnya. ${ }^{3}$

Dengan demikin pemikiran juga termasuk studi yang menekuni hal-hal yang fundamental dalam pengetahuan yaitu paradigma kefilsafatan yang menyangkut asumsi dasar yang disusun sebagai landasan dan kerangka dari suatu bangunan keilmuan. Asumsi dasar tersebut termasuk hal-hal yang diorientasikan untuk memecahkan berbagai persoalan

1 Kaelan, Metode Penelitian Kualitatif bidang Filsafat (Yogyakarta: Paradigma, 2005), 36.

2 Save. M. Dagun, Kamus Besar Ilmu Pengetahuan (Jakarta: Lembaga Pengkajian Kebudayaan Nusantara (LPKN), 1997), 847.

3Johan Meuleman, "Pengantar", dalam Nalar Islami dan nalar Modern: Berbagai Tantangan dan Jalan Baru, Mohammed Arkoun; ter. Rahayu S. Hidayat (Jakarta: INIS, 1994), 21-2. 
menyangkut hubungan subyek dan obyek, tolok ukur validasi keilmuan dan prinsip-prinsip dasar lainnya. ${ }^{4}$

Ilmu pengetahuan mengalami perkembangan yang pesat pada masa modern, di mana masyarakat dianggap telah memasuki tahap berpikir rasional. Pada masa itulah dibangun metodologi yang menjamin kebenaran temuan-temuan pengetahuan manusia. Masyarakat yang mempertahankan keyakinan dan kebenaran agama, dinilai sebagai masyarakat nonrasional yang naif dan subyektif. Bahkan lebih dari itu, masyarakat yang berpola pikir non-rasional yang diidentikkan dengan bangsa Timur, non Barat dianggap sebagai masyarakat berbudaya primitif. Sebagaimana diceritakan Muhadjir, di perguruan tinggi Indonesia sampai tahun 1950-an diajarkan pembedaan antara gemeinschaft atau masyarakat paguyuban, masyarakat Timur yang masih primitif dengan gessellschaft atau masyarakat patembayan yaitu masyarakat Barat yang sudah maju. ${ }^{5}$

Rasionalisme menjadi fondasi ilmu-ilmu pengetahuan modern yang bercorak antroposentris sebagai antitesa terhadap filsafat abad tengah yang bercorak teosentris. Dalam antroposentrisme, manusia menjadi pusat kebenaran, etika, kebijaksanaan, dan pengetahuan, sehingga terjadi diferensiasi (pemisahan) dengan wahyu Tuhan. Kebenaran ilmu tidak terletak di luarnya yaitu kitab suci, tetapi terletak dalam ilmu itu sendiri yaitu korespondensi (kecocokan ilmu dengan obyek) dan koherensi (keterpaduan) di dalam ilmu, antara bagian-bagian keilmuan dengan seluruh bangunan ilmu. Ilmu sekuler dengan demikian menganggap dirinya sebagai ilmu yang obyektif, value free, dan bebas dari kepentingan lainnya. Alur pertumbuhan ilmuilmu pengetahuan modern adalah sebagai berikut:

${ }^{4}$ Lihat, M. Amin Abdullah, "al-Ta'wil al-Ilmi: Kearah Perubahan Paradigma Penafsiran Kitab Suci”, dalam al-Jami'ah Journal of Islamic Studies IAIN Sunan Kalijaga Yogyakarta, volume 39, No. 2, (Juli-Desember 2001), 366.

5 Noeng Muhadjir, Filsafat Ilmu, Kualitatif dan Kuantitatif untuk Pengembangan Ilmu dan Penelitian, Edisi III (Yogyakarta: Rake Sarasin, 2006), 101. 


$$
\text { Filsafat } \longrightarrow \text { antroposentrisme } \longrightarrow \text { diferensiasi } \longrightarrow \text { ilmu sekuler }
$$

Ilmu pengetahuan rasional yang menjadi pilar utama peradaban modern, pada perkembangan terakhirnya, tumbuh dari yang semula mengagungkan manusia menjadi penguasa atas manusia. Ilmu menggantikan kedudukan wahyu Tuhan sebagai petunjuk kehidupan, bahkan ilmu itu sendiri yang diramalkan akan menggantikan agama. ${ }^{6}$

Era modern dengan rasionalisme membuka babak baru hubungan agama dengan ilmu pengetahuan yang penuh konflik dan saling menegasikan. August Comte (abad 19 M), bapak sosiologi modern menyatakan bahwa peradaban modern terjadi bila manusia telah berpikir rasional meninggalkan tahap berpikir teologis dan metafisik. Bila pada tahap berpikir teologis manusia percaya bahwa di balik gejala-gejala alam terdapat kekuasaan adikodrati yang mengatur segalanya kemudian pada zaman metafisika manusia masih dikuasai oleh kekuasaan adikodrati namun melalui konsep-konsep dan prinsip-prinsip yang abstrak seperti "kodrat" dan "penyebab" maka pada zaman yang disebut positif sudah tidak ada lagi penyebab yang ada di belakang faktafakta. Atas dasar observasi dan dengan menggunakan rasionya manusia berusaha menetapkan relasi-relasi atau urutan-urutan yang terdapat di antara fakta-fakta. Dalam zaman inilah manusia baru dicatat sebagai penghasil ilmu pengetahuan yang sesungguhnya. ${ }^{7}$

Ambisi ilmu sekuler untuk meninggalkan agama kenyataannya membawa malapetaka bagi manusia modern sehingga terjadi krisis nilai dan kehidupan yang hampa makna. Untuk itulah, diperlukan usaha untuk mengakurkan kembali antara sains dan wahyu dengan istilah ilmu integralistik, yaitu ilmu yang menyatukan (bukan sekedar menggabungkan) wahyu Tuhan dan temuan pikiran manusia, tidak akan mengucilkan

${ }^{6}$ Kuntowijoyo, Islam Sebagai ilmu, Epistemologi, Metodologi, dan Etika (Bandung: Teraju Mizan, 2004), 51.

${ }^{7}$ Kaelan, Filsafat Bahasa, Masalah dan Perkembangannya (Yogyakarta: Paradigma, 1998), 75-6. 
Tuhan (sekulerisme) dan juga tidak mengucilkan manusia (other worldy asceticisme). ${ }^{8}$

Tulisan ini bertujuan mendeskripsikan dialektika dalam ranah epistemologi peluang wahyu-al-Qur'an untuk dijadikan sebagai sumber ilmu pengetahuan. Analisis akan diperdalam dengan mengelaborasi berbagai pemikiran kontemporer seperti yang digagas oleh Nashr Hamid Abū Zayd, Mohammad Syahrur, Fazlur Rahman dan Kuntowijoyo sehingga dapat dilihat horizon baru dalam melihat masa depan sains dan agama.

\section{Perlunya Revolusi Sains}

Sain modern yang dikuasai oleh idealisme dan empirisme, di mana keduanya sama-sama pada tingkat yang berbeda berobsesi untuk meninggalkan segala sesuatu di luar yang ada. George Berkeley, salah satu Filosof kelahiran Irlandia menyatakan bahwa sama sekali tidak ada substansi-substansi material di luar kita, yang ada hanyalah ciri-ciri yang diamati atau pengamatan dalam roh saja. Segala pengetahuan menurutnya bersandar pada pengamatan. Pengamatan adalah identik dengan gagasan yang diamati. Obyek yang diamati pada hakikatnya terletak pada pengamatan itu sendiri. Obyek berarti gagasan-gagasan atau ideide. ${ }^{9}$

Empirisme adalah yang paling tegas menolak metafisika, bahkan madzhab filsafat yang mencapai kematangannya dalam Vienna Circle atau mazhab Wina ini, penolakan terhadap metafisika telah menjadi tujuannya. Ungkapan-ungkapan tentang segala sesuatu di luar yang ada perlu ditolak karena berpura-pura sebagai ungkapan yang bersifat kognitif, ungkapan metafisika sesungguhnya tidak menyatakan apa-apa sehingga bersifat 'nirarti' atau tidak bermakna. ${ }^{10}$

Konstruksi sains modern kemudian dibangun dengan kokoh dengan mesin yang bernama metode bypotetic-deduktive. Para saintis mengoperasikan teorinya terhadap fakta-fakta dalam model logika jika-maka atau if-then. Skema inilah yang menjamin eksistensi sebuah teori dengan menguji secara terus menerus

\footnotetext{
${ }^{8}$ Kuntowijoyo, Islam Sebagai..., 51.

${ }^{9}$ Kaelan, Filsafat Bahasa..., 64.

${ }^{10}$ Ibid., 122.
} 
dengan fakta. Rolston juga menampilkan uji verifikasi dan falsifikasi. Verifikasi merupakan sarat penting bagi metode deduktif agar preposisi yang diajukan dinilai bermakna. Suatu dalil, teori atau aksioma dianggap memiliki makna bila secara prinsip dapat diverifikasi. Uji verifikasi ini dianggap oleh pengkritiknya sebagai hanya mengumpulkan data yang relevan atau mendukung teorinya, untuk itu kelompok ilmuwan lain mengeluarkan uji falsifikasi atau uji penolakan atas teorinya. Metode deduktif dan alat-alat pengujinya merupakan bagian dari sistem sains modern, bagaimana sesungguhnya dialektika epistemologis di dalamnya?.

Hubungan subyek-obyek mengenai siapa itu manusia yang menjadi subyek dari pengetahuan dan apa itu realitas sebagai obyek dalam konstruksi sains modern menimbulkan keraguan. Pertanyaan yang muncul mengamati konstruksi sains modern di atas adalah apakah ada subyek yang sepenuhnya dapat menangkap realitas obyek dan adakah realitas obyek yang sepenuhnya dapat ditangkap oleh obyek. Para saintis dan filosof yang bermadzhab kritis ragu atas kemutlakan baik kekuasaan subyek atau obyek. Immanuel Kant (1724-1804), filosof asal Jerman menyatakan bahwa manusia tidak akan pernah sampai terhadap realitas itu sendiri (das ding an sich). Hal itu karena penglihatan manusia terhadap suatu obyek sangat ditentukan oleh perangkat mental yang telah terbentuk dalam pikiran manusia akibat bentukan ruang waktu. Pengaruh ruang dan waktu inilah yang dirumuskan oleh Kant sebagai kategorikategori dalam pikiran yang berperan menjadi semacam kacamata bagi penglihatan mata. Apabila seseorang memakai kacamata biru, maka obyek di luar akan tampak biru. ${ }^{11}$

Pandangan Kant yang menyimpulkan bahwa dalam ilmu pengetahuan manusia tidak dapat mencapai suatu kepastian meruntuhkan mitos yang didengungkan sains modern terutama oleh positivisme logis. Munculnya Kant sebenarnya pada puncak perkembangan positivisme yang diketahui secara umum bahwa ilmu pengetahuan yang telah dihasilkan oleh beberapa ilmuwan

11 Bertrand Russel, Sejarah Filsafat Barat, ter. Sigit Jatmiko, dkk. (Yogyakarta: Pustaka Pelajar, 2004), 923-4. 
mampu menemukan dalil atau hukum-hukum yang sifatnya berlaku umum. ${ }^{12}$

Pandangan Kant juga sekaligus memecah kebuntuan dimana sains modern tidak lagi sanggup mengembangkan ilmu pengetahuan. Dengan logika positivis, sains hanya bergerak untuk menguji teori (verifikasi) bukan bagaimana menghasilkan satu perspektif baru dari ilmu pengetahuan. Perspektif baru tersebut tercapai bila cara pandang baik terhadap subyek maupun obyek dapat dilampaui. Sebagaimana pendapat Kant, manusia melihat obyek senantiasa ditentukan oleh kategorikategori tertentu. Menurut Thomas Kuhn bahwa pada dasarnya realitas sosial itu dikonstruksi oleh mode of thought atau mode of inquiry tertentu, yang pada gilirannya akan menghasilkan mode of knowing tertentu pula, Marx menamakannya sebagai ideologi, dan Wittgenstain melihatnya sebagai cagar bahasa. Kategori dan istilah-istilah itulah yang disebut paradigma. ${ }^{13}$

Konsep Kuhn tentang paradigma di atas digagas untuk menolak anggapan yang selama ini berkembang dikalangan ilmuwan bahwa ilmu itu terjadi secara kumulatif di mana kebenaran suatu teori dikuatkan secara terus menerus dengan hasil penelitian terbaru yang membuktikan kebenarannya. Menurut Kuhn perkembangan ilmu pengetahuan terjadi secara revolusi dengan skema sebagai berikut:

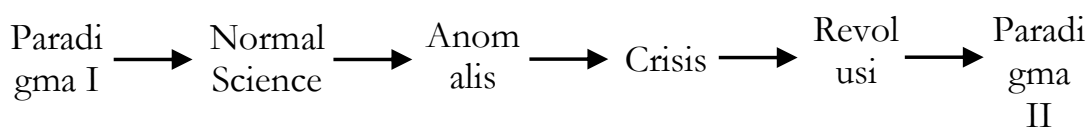

Ilmu pengetahuan pada waktu tertentu didominasi oleh suatu paradigma tertentu yang membimbing sang ilmuwan untuk melakukan kegiatan ilmiahnya sehingga terbangun suatu ilmu pengetahuan (normal science). Pada saat tertentu akan terjadi krisis di mana teori-teori yang dibangun tidak dapat lagi menjelaskan fakta-fakta yang ada. Dalam situasi krisis inilah ilmuwan akan melakukan revolusi sehingga melahirkan paradigma baru. ${ }^{14}$

\footnotetext{
${ }^{12}$ Kaelan, Filsafat Bahasa..., 70.

${ }^{13}$ Kuntowijoyo, Islam sebagai..., 11-2.

${ }^{14}$ Greg Soetomo, Sains dan Problem Ketuhanan (Yogyakarta: Kanisius,
} 1995), 21. 
Bagi pengembangan ilmu, ilmuwan dapat mengkonstruk paradigma baru, dan menawarkan atau dibuat orang paham tentang paradigma yang ditawarkan. Setidaknya orang paham paradigma baru tersebut dalam discourses, apakah ahli lain sepakat atau tidak, itulah paradigma sebagai model. ${ }^{15}$

\section{Al-Qur'an Sebagai Paradigma}

Melakukan revolusi sains diperlukan kehati-hatian dengan tidak bersikap emosional sehingga seolah apa yang dihasilkan pada masa lalu adalah gagal total. Umat Islam sering terjebak pada apologi khususnya para ilmuwan di lingkuangan religious studies. Mereka berangkat dari wilayah normative sehingga memiliki asumsi bahwa hanya wahyu yang mutlak benar, dan sains modern bersifat nisbi. Menurut Kuntowijoyo, seorang cendekiawan muslim Indonesia, bahwa:

"Ilmu-ilmu sekuler tersebut adalah produk bersama seluruh manusia, sedangkan ilmu-ilmu integralistik (nantinya) adalah produk bersama seluruh manusia beriman. Karenanya, sekarang ini kami semua adalah produk, partisipan, dan konsumen ilmu-ilmu sekuler. Maka kami tidak akan gegabah memandang rendah dan menistakan ilmu-ilmu sekuler, tempat kami lahir. Sebaliknya, kami ingin menghormatinya dengan mengkritisi dan meneruskan perjalannya" 16 .

Positivisme dengan berpandangan bahwa sains modern yang bertumpu pada rasionalisme bermusuhan dengan agama yang dinilai menyerukan cara berpikir mistis sudah saatnya ditinjau kembali seiring dengan kebuntuan sains modern sebagaimana terungkap dengan perspektif Thomas Khun di atas. Sains modern dan agama, dari segi isi material, secara tipikal samasama menawarkan alternatif interpretasi tentang pengalaman. Perbedaannya bahwa interpretasi sains didasarkan pada kausalitas, sedang interpretasi agama didasarkan pada makna. Di dalam keduanya ada penekanan yang berbeda dalam bentuk format logiknya, tetapi keduanya adalah rasional dan sama-sama terbuka untuk mengembangkan diri melewati zaman. Baik agama maupun sains, sama-sama menggunakan paradigma teoritis sebagaimana mereka menghadapi pengalaman. Konflik

15 Noeng Muhadjir, Filsafat Ilmu, Kualitatif dan Kuantitatif untuk Pengembangan Ilmu dan Penelitian (Yogyakarta: Rake Sarasin, 2006), 10.

${ }^{16}$ Kuntowijoyo, Islam Sebagai..., 51. 
antara interpretasi sains dan agama muncul hanya karena batas antara kausalitas dan makna adalah tidak tetap. ${ }^{17}$

Pernyataan di atas membuka masalah akademik yang mendasar baik dalam level ontologis apa hakikat dari agama dan sains, maupun pada level epistemologis apa sebenarnya yang disebut pengetahuan yang benar, yang ilmiah dan yang obyektif. Bila benar sains telah merebut klaim kebenaran yang dimiliki agama dan sekarang terbukti bahwa klaim kebenaran universal dari sainspun juga tidak meyakinkan, maka di masa yang akan datang sangat dibutuhkan ilmu pengetahuan yang mengintegrasikan antara sumber rasional dan agama (wahyu) sebagai sumber pengetahuan. Ilmu pengetahuan yang integralistik menempatkan dua sumber pengetahuan, yaitu Tuhan yang berupa wahyu dan manusia yang berupa akal.

Agama menyediakan tolok ukur kebenaran ilmu (benar, salah), bagaimana ilmu diproduksi (baik, buruk), dan tujuantujuan ilmu (manfaat, merugikan). Hak manusia adalah memikirkan dinamika internal ilmu sehingga menjadi ilmu yang obyektif. Meskipun ilmu integralistik lahir dari agama, namun menjadi gejala keilmuan yang obyektif yang dirasakan sebagai gejala keilmuan bukan norma oleh pemeluk agama lain, nonagama dan anti-agama. Alur ilmu-ilmu integralistik adalah sebagai berikut: ${ }^{18}$

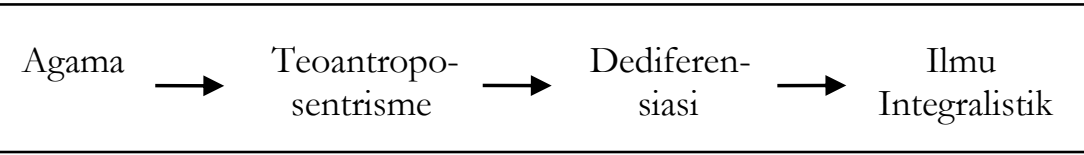

Menjadikan wahyu (baca: al-Qur'an) sebagai paradigma berarti menjadikan al-Qur'an sebagaimana dipahami Thomas Kuhn sebagai suatu konstruksi pengetahuan yang memungkinkan umat Islam memahami realitas sebagaimana alQur'an memahaminya. Konstruksi pengetahuan tersebut akan menjadi dasar bagi umat untuk merumuskan desain besar mengenai sistem Islam termasuk sistem ilmu pengetahuannya. Dengan demikian paradigma al-Qur'an tidak hanya berhenti

${ }^{17}$ Holmes Rolston, Science and Religion, a Critical Survey (New York: Random House, 1987), 1.

${ }^{18}$ Kuntowijoyo, Islam Sebagai..., 51. 
pada kerangka aksiologis tetapi juga dapat berfungsi memberi kerangka epistemologis. ${ }^{19}$

\section{Kritik terhadap Pemikiran Studi al-Qur'an Klasik Sampai Masa Pertengahan}

Usaha untuk menjadikan al-Qur'an sebagai paradigma sehingga bisa dijadikan sumber ilmu pengetahuan memerlukan revolusi di bidang ilmu al-Qur'an dan ilmu tafsir al-Qur'an. Konstruksi pemikiran Islam abad pertengahan yang cenderung ortodoks, menjadikan usaha untuk mendekatkan al-Qur'an dengan ilmu pengetahuan berjalan terseok-seok. Hubungan dengan kalangan filosof dan ahli logika dalam interprestasi terhadap sumber hukum Islam, yaitu al-Qur'an dan hadis, diperketat bahkan cenderung dibatasi. Sebagaimana disinyalir oleh Nashr Hamid Abū Zayd, sikap dan wacana keagamaan terhadap ilmu-ilmu keislaman, khususnya al-Qur'an dan hadis pada masa pertengahan adalah hanya sikap pengulangan. Hal tersebut terjadi karena banyak diantara ulama yang berasumsi bahwa ilmu-ilmu al-Qur'an dan al-Hadis termasuk ruang lingkup ilmu yang sudah matang dan final (nadijat wa ịtarakat). ${ }^{20}$ Para ulama memandang karya tafsir tidak sebagai upaya mendialogkan teks al-Qur'an dengan realitas masyarakat yang sedang berlangsung, tetapi pada konsistensinya untuk mengikuti jejak ulama terhadulu (salaf) yang menafsirkan al-Qur'an dengan metode naql yaitu dengan al-Qur'an sendiri, al-sunnah, pendapat para sahabat dan tabi'in.

Ibn Taymiyyah, salah seorang ulama abad VIII Hijriah menegaskan bahwa apabila telah diketahui pengertian atau tafsir al-Qur'an dengan al-sunnah maka tidak diperlukan lagi pendapat ahli bahasa dan yang lainnya. Bagi setiap mukmin tidak diperkenankan berbicara mengenai agama kecuali mengikuti apa yang datang dari Rasulullah saw., para sahabat dan orang-orang yang mengikuti jejak mereka dari para tabi'in, yang tak

${ }^{19}$ Ibid., 11-2.

${ }^{20}$ Nashr Hamid Abū Zayd, Mahfüm al-Naș, Dirāsah fì Ulüm al-Qur'ān, (Kairo: al-Hay’ah al-Mișriyyah al-Ammah li al-Kitab), 13. 
seorangpun diantara mereka terbukti melakukan pertentangan dengan al-Qur'an dengan rasionalitasnya. ${ }^{21}$

Al-Zarkasyi, seorang ulama yang wafat pada tahun $794 \mathrm{H}$, penulis kitab al-Burhān fì 'Ulüm al-Qur'ān, salah satu kitab rujukan utama dalam bidang ilmu-ilmu al-Qur'an juga menyimpulkan bahwa yang benar menurut ilmu tafsir adalah apa yang berasal dari jalur naql (periwayatan) seperti asbāb al-nuzūl (sebab turunnya ayat), al-nasikh wa al-mansukh (diberlakukan atau dihapuskannya ketetapan hukum yang dikandung oleh suatu ayat yang belum jelas) ta'yin al-mubham (penjelasan terhadap ayat yang belum jelas), tabyin al-mujmal (penjelasan terhadap ayat yang masih umum). Apabila tidak didapatkan penafsiran yang cukup dari jalan naql, maka untuk mengetahui makna dan maksud dari ayatayat al-Qur'an adalah dengan jalan pemahaman pada penjelasan yang mu'tabar (terkenal dan diakui oleh kebanyakan ulama). ${ }^{22}$

Tafsir dengan pendekatan seperti itu, yang disebut tafsì bi alma'thür menurut al-Qațtan, wajib diikuti dan dipedomani karena ia adalah jalan pengetahuan yang benar dan merupakan jalan paling aman untuk menjaga diri dari ketergelinciran dan kesesatan dalam memahami kitabullah. ${ }^{23}$ Sebaliknya, tafsir yang mencoba merespon perkembangan zaman dengan menghadirkan ilmu-ilmu seperti bahasa, hukum, sastra, termasuk filsafat sebagai ilmu bantu dalam menyingkap makna al-Qur'an adalah karya yang dilarang (haram) yang berarti juga haram megikutinya. Hal tersebut dikarenakan ketepatan dan kebenaran suatu pendapat tidak meyakinkan dan hanya bersifat dugaan dan perkiraan semata. Orang yang mengatakan sesuatu tentang agama Allah menurut dugaan semata berati ia telah mengatakan terhadap Allah sesuatu yang tidak ia ketahui. ${ }^{24}$ Ibn Taymiyyah juga secara tegas mengklaim bahwa sebab-sebab kesesatan dalam

21‘Abd al-Raḥmān bin Muḥammad bin Qāsim al-'Așim al-Najdi, Majmū' Fatawa Syaykh al-Islàm Aḅmad bin Taymiyyah (Tt: tpn, 1398 H), Juz 13 -Kitab Muqaddimat al-Tafsir, 27 dan 63

${ }^{22} \mathrm{Badr}$ al-Dīn Muḥammad bin 'Abd al-Lah al-Zarkashi, al-Burhan fi 'Ulüm al-Qur'ān (Beyrut: Dār al-Fikr, 1998), juz 2, 188-9

${ }^{23}$ Mannā' al-Qațān, Mabāhith fì Ulüm al-Qur'ān (Riyaḍ: Manshurat al'Așr al-Hadith, 1973), 350.

${ }^{24}$ Ibid., 352. 
penafsiran al-Qur'an adalah adanya interaksi dengan para filosof. 25

Tafsir yang wajib dijadikan pedoman yaitu yang menggunakan metode tafsìr bi al-ma'thür, menunjukkan bahwa gerak tafsir al-Qur'an yang diorientasikan oleh nalar Arab adalah untuk mencari landasan teologis, pembenar dari Yang Maha Benar (al-Haq), kepastian dari Yang Maha Absolut terhadap semua persoalan kebudayaan. Produk pemikiran manusia hanya akan menghantarkan pada ketidakpastian dan menjerumuskan pada kesesatan, maka sebagai jalan keluarnya adalah kembali kepada pemahaman yang paling benar dari wahyu al-Qur'an dan yang paling mengetahui maksud Tuhan sebagai pengirim wahyu al-Qur'an adalah Nabi Muhammad dan para sahabat yang disebut sebagai generasi terbaik (khayr al-qurün). Antropologi dikubur sebagai barang sesat dan manusia harus mengikuti logika Tuhan yang sebenarnya hanyalah logika orang-orang Arab (yang primitif).

Dialektika halal-haram dalam ilmu-ilmu al-Qur'an jelas menutup dialektika keilmuan dan memasukkan ruang akademik ke dalam ruang teologis yang hitam-putih. Hal ini berakibat pada dinamika pemikiran Islam yang merujuk pada sumber al-Qur'an dan al-Sunnah tidak terakomodasi dengan kerangka metodologi yang memadai. Muhammad Syahrur, seorang insinyur muslim yang menaruh minat pada studi al-Qur'an, dalam pengantar bukunya al-Kitäb wa al-Qur'ān, Qiräah Mua'shirah, ia menyatakan bahwa telah berlalu paruh kedua dari abad ke-15 $\mathrm{H}$, atau bertepatan dengan paruh terakhir abad ke-20 M, tetapi peradaban Islam sejak permulaan abad ke-20 masih saja menyuguhkan Islam sebagai aqidah dan etika tanpa menyentuh dimensi filosofis dari aqidah Islam. Peradaban Islam mengalami stagnasi dan tidak mampu memecahkan problem fundamental pemikiran ke-Islaman, karena masih dipenuhi berbagai taklid tentang konsep qadha' dan qadar, paham jabariah, problematika pengetahuan, konsep negara, problem sosial ekonomi, demokrasi dan penafsiran atas sejarah. Syahrur merumuskan bahwa masalah utama dari semuanya adalah:

25‘Abd al-Raḥmān, Majmū’ Fatawa..., 206. 
1. Tidak adanya pegangan berupa metode ilmiah objektif.

2. Adanya prakonsepsi terhadap semua masalah sebelum kajian dilakukan. Contohnya penelitian mengenai "Posisi Perempuan dalam Islam". Para peneliti muslim berkesimpulan terlebih dahulu sebelum mengadakan penelitian. Mereka berasumsi bahwa posisi perempuan dalam Islam sudah proporsional dan Islam adalah agama yang bersikap paling adil terhadap perempuan. Kemudian peneliti tersebut mengarang buku mengenai perempuan.

3. Pemikiran Islam belum memanfaatkan konsep-konsep dalam filsafat humaniora dan tidak berinteraksi dengan dasar-dasar teorinya.

4. Tidak adanya teori Islam kontemporer dalam ilmu humaniora yang disimpulkan secara langsung dari alQur'an. ${ }^{26}$

Nashr Hamid Abū Zayd, menilai karya-karya ulama klasik telah menyebabkan tergantikannya teks pertama (al-Qur'an) dengan teks-teks sekunder (sunnah $\mathrm{Nabi}$ dan interpretasiinterpretasi ulama). Pendapat Abū Zayd terhadap ulama mutaqaddimin tersebut di antaranya diwujudkan dalam karyanya al-Imām al-Shäfi'i wa Ta'sìs al-Aydyülujizya al-Wasatiyyah (Imam Syafi'i dan Pendirian Ideologi Moderat). Buku tersebut memuat kritik atas pendiri madzhab hukum Islam Syafi'iyah, al-Imām alShāfi'̄ (150-204 H). Buku ini juga memuat kritik terhadap ideologi moderat dalam Islam secara umum, yang dimapankan oleh Abu Hasan al-Asy'ari (wafat $330 \mathrm{H}$ ) dalam bidang teologi, dan Abu Hamid al-Ghazali (wafat $505 \mathrm{H}$ ) dalam bidang pemikiran Islam dan tasawuf. ${ }^{27}$

Tesis Magister Abū Zayd mengenai muktazilah dan Disertasinya mengenai Filsafat Takwil Ibn Araby juga mengantarkannya pada kesimpulan bahwa pergulatan agama dan teks-teks keagamaan yang direpresentasikan dalam wacana keagamaan dominan di Mesir pada tahun 1950-an dan 1960-an

26 Muhammad Syahrur, al-Kitāb wa al-Qur'ān, Qira'ah Mu'ashirah (Damaskus: al-Ahali, 1990), 29-32

27 Moch Nur Ichwan, Meretas Kesarjanaan Kritis al-Qur'an,Teori Hermeneutika Nashr Abu Zayd (Jakarta: Teraju, 2003), 21-2. 
sebagai sebuah agama sosialisme dan nasionalisme Arab, dan sebagai sebuah agama pembangunan dan perdamaian pada tahun 1970-an. Perubahan dalam perepresentasian Islam tersebut menurut penelitian Abū Zayd disebabkan oleh interpretasi ideologis terhadap Islam. Agama Islam dipaksakan untuk mengabdi kepada ideologi hegemonik. ${ }^{28}$

Kuntowijoyo, juga berkesimpulan bahwa selama ini gerak studi keislaman masih belum keluar dari pola ideologis. Ada dua cara pandang umat terhadap al-Qur'an sebagai kerangka rujukan, 1) dekodifikasi (penjabaran) yaitu menjaga nilai-nilai agama tetap sesuai aslinya dengan menjabarkan al-Qur'an dan al-sunnah kedalam ilmu-ilmu agama. Cara pandang ini melahirkan gerakan dari teks ke teks, yaitu dari teks (al-Qur'an dan al-sunnah) dijabarkan kedalam teks (tafsir, tasawuf, dan fiqh). 2) Islamisasi pengetahuan, yaitu usaha agar umat Islam tidak asal meniru metode-metode dari luar dengan mengembalikan pengetahuan pada pusatnya, yaitu taubid. Islamisasi pengetahuan berarti mengembalikan pengetahuan pada tauhid, atau konteks kepada teks, supaya pengetahuan tidak lepas dari iman. Baik dekodifikasi, yang menjabarkan teks kedalam teks maupun islamisasi pengetahuan yang mengembalikan konteks ke teks, sama sekali belum meyentuh persoalan "konteks" di mana segala persoalan kemanusiaan dan kemasrakatan berkembang.

\section{Konstruksi Metodologi Tafsir Kontemporer}

Niatan yang kuat untuk keluar dari krisis pemikiran dan sakit mental yang traumatik terhadap dunia luar dengan mengarahkan dunia akademik di era kontemporer lebih berorientasi kepada usaha menemukan metode-metode ilmiah yang dapat dipertanggungjawabkan secara ilmiah dalam menafsirkan alQur'an begitu dirasakan para cendekiawan muslim. Keresahan tersebut terangkum dalam pernyataan Quraish Shihab, bahwa di antara faktor-faktor yang mengakibatkan kelemahan dalam penafsiran al-Qur'an antara lain:

1. Subyektivitas mufasir

2. Kekeliruan dalam menerapkan metode dan kaidah

${ }^{28}$ Ibid., 19. 
3. Kedangkalan dalam ilmu-ilmu alat

4. Kedangkalan pengetahuan tentang materi uraian (pembicaraan) ayat

5. Tidak memperhatikan konteks, baik asbāb al-nu₹ūl, hubungan antar ayat, maupun kondisi sosial masyarakat.

6. Tidak memperhatikan siapa pembicara dan terhadap siapa pembicaraan ditujukan. ${ }^{29}$

Menurut Nashr Hamid Abū Zayd, membangun sebuah metodologi yang ilmiah dalam studi al-Qur'an merupakan jalan satu-satunya untuk mencapai obyektivitas pemahaman terhadap al-Qur'an dan Islam secara keseluruhan. Ungkapan Abū Zayd tersebut didasarkan pada kenyataan kuatnya tarikan-tarikan ideologis dalam pemikiran Islam yang sulit dihindarkan oleh para pengkaji dan peneliti ketika memasuki wilayah kajian Islam. ${ }^{30}$

Pembaharuan metodologi tafsir meniscayakan pergeseran cara pandang terhadap al-Qur'an sebagai obyek kajian. Abū Zayd, sebagai seorang pembaharu di era kontemporer telah menegaskan bahwa masalah utama dalam studi al-Qur'an adalah mengembalikan kaitan antara kajian-kajian al-Qur'an dengan kajian-kajian dan kritik sastra. Antara kajian al-Qur'an dengan sastra tersusun dari berbagai ilmu yang porosnya satu, yaitu teks, baik teks tersebut berupa al-Qur'an ataupun hadis Nabi. Tidak ada perbedaan metodologis dan pendekatan-pendekatan kritis dalam mempelajari teks-teks sastra, perbedaannya hanya dalam menentukan hakikat "teks", karakteristik, dan fungsinya. ${ }^{31}$

Statemen dari Abū Zayd di atas sangatlah menarik sebagai sebuah langkah maju untuk menemukan metode ilmiah dalam studi al-Qur'an, namun ide tersebut sekaligus menjadi ide yang kontroversial. Keberatan yang segera muncul adalah bagaimana mungkin menerapkan metode analisis teks terhadap teks ketuhanan?. Meskipun tidak bersifat mengada-ada dan berpijak dengan argumentasi baik historis maupun rasional yang kuat,

${ }^{29}$ M. Quraish Syihab, Membumikan al-Qur'an, Fungsi dan Peran Wabyu dalam Kehidupan Masyarakat (Bandung: Mizan, 1999), 79.

${ }^{30} \mathrm{Nashr}$ Hamid Abu Zayd, Tekstualitas al-Qur'an, Kritik terhadap Ulumul Qur'an, ter. Khoiron Nabdliyin (Yogyakarta: LKiS, 2001), 16.

${ }^{31} \mathrm{Abū}$ Zayd, Mahfüm al-Nash...,18. 
namun pemikiran Abū Zayd mengenai tekstualitas al-Qur'an untuk mengembalikan studi al-Qur'an pada porosnya sebagai teks kebahasaan telah disalahpahami oleh sebagian ulama Mesir. Ulama tersebut menganggap Abū Zayd murtad di antaranya dengan alasan, pertama: Abū Zayd berpendapat dan mengatakan bahwa al-Qur'an adalah produk budaya (muntaj thaqafi), dan karenanya mengingkari status azali al-Qur'an sebagai Kalamullah yang telah ada dalam al-Lawh al-Mahfüz, dan kedua, Abū Zayd berpendapat dan mengatakan bahwa al-Qur'an adalah teks linguistik (nas lugawr), Ini sama dengan mengatakan bahwa Rasulullah Saw. telah berdusta dalam menyampaikan wahyu dan al-Qur'an adalah karangan beliau. ${ }^{32}$

Abū Zayd sama sekali tidak mengingkari hakikat al-Qur'an sebagai Kalamullah. Abū Zayd menyatakan bahwa dalam hubungan linguistik terdapat interaksi antara pengirim dan penerima. Dalam konteks al-Qur'an pengirimnya adalah Allah. Oleh karena pengirim dalam konteks al-Qur'an adalah Allah, maka tidak dapat dijadikan objek kajian. Abū Zayd kemudian menawarkan objek kajian dalam studi al-Qur'an berupa realitas budaya yang terjadi pada fase pembentukan dan penyempurnaan. Dengan demikian, pendapat Abū Zayd bahwa al-Qur'an adalah teks linguistik, tidaklah menafikan realitas alQur'an sebagai Kalamullah pada masa pewahyuan. Karena setelah masa pewahyuan berlangsung masa berikutnya sebagai apa yang disebut masa pembentukan, di mana al-Qur'an sebagai teks kebahasaan yang dibaca dan dikaji oleh umat manusia. Interaksi masyarakat dengan al-Qur'an inilah yang dimaksud Abū Zayd sebagai realitas budaya yang dapat dijadikan objek studi al-Qur'an. ${ }^{33}$

Sejalan dengan usaha Abū Zayd untuk mendudukkan alQur'an sebagai objek kajian dengan memilah antara sakralitas dan tekstualitas al-Qur'an, Syahrur seorang pemerhati tafsir alQur'an juga berusaha membedakan antara al-Qur'an sebagai teks yang sakral dan al-Qur'an sebagai sebuah teks yang ditafsirkan.

${ }^{32}$ Syamsuddin Arief, Kisah Intelektual Nashr Hamid Abu Zayd, Pengusung Tafsir Hermeneutika, http://indrayogi.multiply.com/reviews/item/89, 14 Agustus 2010.

${ }^{33} \mathrm{Abū}$ Zayd, Mahfüm al-Nash..., 24. 
Syahrur membedakan antara istilah al-kitäb dengan al-Qur'ān. Menurut Syahrur al-Kitäb bukan teks budaya dalam pengertian yang dihasilkan oleh manusia, tetapi wujud teks al-Kitab adalah teks berbahasa Arab, dimana bahasa Arab adalah hasil budaya masyarakat Arab yang tidak bisa dilepaskan dengan struktur nalar dan sosial masyarakat Arab. Untuk itu Syahrur berkesimpulan bahwa dari sisi kandungannya (al-mubtawa) mengandung unsur Ilahiah yang absolut, namun pada sisi pemahaman terhadap al-Kitab bersifat insani yang relatif. Manusia tentu tidak bisa menangkap keseluruhan wahyu yang absolut, untuk menangkapnya Tuhan telah menurunkan wahyu dengan medium yang memungkinkan manusia bisa memahaminya yaitu bahasa. Dengan demikian, relatifitas yang dimaksud Syahrur adalah relatifitas dalam kerangka hubungan antara pembaca dengan teks al-Qur'an yang berbahasa Arab. ${ }^{34}$

Abū Zayd juga sependapat dengan Syahrur bahwa relatifitas dalam konteks al-Qur'an adalah relatifitas dalam kerangka hubungan antara pembaca dengan teks al-Qur'an yang berbahasa Arab. Menurut Abū Zayd kata-kata literal (mantūq) teks Qur'an bersifat ilahiah, namun ia menjadi sebuah "konsep" (mafhüm) yang relatif dan bisa berubah ketika ia dilihat dari perspektif manusia; ia menjadi sebuah teks manusiawi. Dari momen bahwa teks diwahyukan dan dibaca oleh $\mathrm{Nabi}$, ia tertransformasikan dari sebuah teks ilahi (naș ilähi) menjadi sebuah konsep mafhüm atau teks manusiawi (nas insāni), karena ia secara langsung berubah dari wahyu (tan $2 i)$ menjadi interpretasi (ta'mil). Pemahaman Muhammad atas teks merepresentasikan tahap paling awal dalam interaksi teks dengan pemikiran manusia. ${ }^{35}$

Konsep tekstualitas al-Qur'an dan hubungan subyek-obyek dalam studi al-Qur'an di atas membawa konsekuensi metodologis yang dapat dipilah dalam tiga hal berikut: pertama, kata wabyu dalam Qur'an secara semantik setara dengan perkataan Allah (kalam Allah) dan Qur'an adalah sebuah pesan

${ }^{34}$ Syahrur, al-Kitāb wa al-Qur'ān..., 36.

${ }^{35}$ Moch Nur Ichwan, “al-Qur'an sebagai Teks (Teori Teks dalam Hermeneutik Qur'an Nasr Hamid Abu Zayd)" dalam Abdul Mustaqim dan Sahiron Syamsudin,ed., Studi al-Qur'an Kontemporer, Wacana Baru Berbagai Metodologi Tafsir (Yogyakarta: Tiara Wacana, 2002), 158. 
(risälab). Sebagai perkataan dan pesan, Qur'an meniscayakan dirinya untuk untuk dikaji sebagai sebuah "teks". Kedua, urutan tekstual surat dan ayat dalam teks Qur'an tidak sama dengan urutan kronologis pewahyuan. Urutan kronologis pewahyuan (tanjim) Qur'an merefleksikan historisitas teks, sementara struktur dan urutan yang ada seperti sekarang merefleksikan tekstualitasnya. Sebuah genre spesifik dalam ilmu Qur'an, korelasi antara ayat dan surat ('ilm al-munāsabah bayn al-äyat wa alsuwar), telah diciptakan untuk menyediakan kepada penafsir sebuah interaksi aktif dengan teks, karena dalam korelasi ini tersimpan kemungkinan-kemungkinan yang bisa terungkap dalam proses pembacaan. Ketiga, Qur'an terdiri dari ayat-ayat mubkamat (ayat-ayat yang jelas) yang merupakan induk (backbone) teks, ayat-ayat mutashäbiḩat (ayat-ayat ambigu), yang harus dipahami berdasarkan atas ayat-ayat mubkamat. Keberadaan dua macam ayat ini merangsang pembaca bukan hanya untuk mengidentifikasi ayat-ayat mutashābiḩat, namun juga membuatnya bisa menentukan bahwa ayat-ayat mubkamat adalah kunci untuk melakukan penjelasan dan klarifikasi terhadap ayat-ayat mutashābiḩat. ${ }^{36}$

Hubungan pembaca dengan teks al-Qur'an yang berbahasa Arab (insani) meniscayakan ilmu bahasa sebagai sebuah metode penafsiran untuk menangkap makna al-Qur'an. Syahrur menetapkan pemikiran linguistik kontemporer sebagai rujukan, hal ini sebagai bentuk konsistensi Syahrur terhadap pernyataannya tentang temporarilitas pemahaman. Sebagai manusia yang hidup di zaman kontemporer, maka harus memaksimalkan seluruh pemikiran kontemporer. Namun Syahrur juga tidak asal comot dan pilih teori, terbukti Syahrur berinteraksi dengan baik dengan linguis Arab kontemporer.

Berbeda dengan semua teks hasil budaya yang ada yang ditulis sebagai ungkapan kegelisahannya pada masa itu atau sebagai respon terhadap situasi zaman tertentu dimana ia menetap dan berkarya, al-Kitab sebagai wahyu ditujukan kepada semua manusia di segala tempat dan segala zaman. Untuk itu menurut Syahrur pemahaman kita terhadap teks al-Kitab tidak bisa dibatasi atau ditentukan oleh satu pemahaman dari periode

36Ibid., 154-5. 
masyarakat tertentu termasuk periode Nabi Muhammad saw. Pemahaman yang dilakukan Nabi dan sahabat dianggap Syahrur sebagai contoh pertama pemahaman terhadap al-Qur'an untuk mengahadapi masalah zamannya. ${ }^{37} \mathrm{Di}$ sinilah muncul persoalan hermeneutik yaitu jarak antara teks yang diturunkan di sana pada zaman dahulu dengan kita yang di sini yang hidup dengan permasalah zaman ini.

Mengatasi kesenjangan makna antara yang dihasilkan masyarakat Arab pada masa pewahyuan dengan tuntutan masyarakat kekinian, maka Fazlur Rahman mengusulkan agar pemahaman atas al-Qur'an tidak hanya menggunakan pendekatan ilmu bahasa dan kritik sastra, namun juga menyertakan dimensi historis-sosiologis yang menyertai masyarakat Arab tersebut. Dialektika antara teks, Muhammad, dan realitas sosial ini dapat menghasilkan makna yang kemudian diambil darinya makna substantif untuk diterapkan dalam situasi kekinian. Dimensi historis-sosiologis dipandang sebagai latar belakang yang menjadi suatu kesatuan dalam memahami alQur'an. Latar belakang pertamanya adalah aktivitas Nabi sendiri dan perjuangannya selama kurang lebih dua puluh tiga tahun di bawah bimbingan al-Qur'an. Karena perjuangan Nabi sendirilah yang sesungguhnya berhak memperoleh sebutan Sunnah, maka adalah penting untuk memahami sebaik mungkin milieu Arab pada masa awal penyebaran Islam, sebab aktivitas Nabi mensyaratkan adanya milieu tersebut. Dengan demikian adat istiadat, pranata-pranata dan pandangan hidup orang-orang Arab pada umumnya menjadi sangat penting untuk memahami aktivitas Nabi. Situasi di Makkah, khususnya, segera sebelum Islam datang juga membutuhkan suatu pemahaman yang mendalam. ${ }^{38}$

Konsep metode penafsiran yang diusulkan Rahman di atas kemudian dirumuskan menjadi metode penafsiran yang terdiri dari dua gerakan (double movement). Pertama, dari yang khusus (partikular) kepada yang umum (general) dan kedua, dari yang umum kepada yang khusus. Gerakan pertama, bertujuan untuk

${ }^{37}$ Syahrur, al-Kitāb wa al-Qur'ān..., 44-5.

${ }^{38}$ Taufik Adnan Amal, ed., Metode Alternatif Neomodernisme Islam Fazlur Rahman (Bandung: Mizan, 1987), 55. 
memahami prinsip-prinsip umum al-Qur'an dan sunnah, sebagai bagian organis dari al-Qur'an dan gerakan kedua bertujuan merealisasikan tujuan moral sosial al-Qur'an tersebut pada situasi atau kasus aktual sekarang ini.

Gerakan pertama, terdiri dari dua langkah yang harus ditempuh, yaitu; pertama, memahami makna ayat-ayat spesifik alQur'an dengan mengkaji situasi atau problem historis yang ingin dijawab ayat tersebut. Selain itu, harus dikaji pula situasi makro dalam batasan-batasan masyarakat, agama, adat-istiadat, lembaga, bahkan keseluruhan kehidupan masyarakat di Arabia pada saat Islam datang, khususnya Mekkah dan sekitarnya. Kedua, menggeneralisasikan respon-respon spesifik penurunan wahyu al-Qur'an dan menyatakannya sebagai ungkapan-ungkapan yang memiliki tujuan moral sosial umum. ${ }^{39}$

Contoh mengenai sebuah preposisi umum di dalam alQur'an, misalnya adalah pernyataan al-Qur'an bahwa, "kekayaan tidak boleh beredar hanya di kalangan golongan kaya dalam masyarakat" (Qs. 59:7), tetapi harus beredar dalam seluruh masyarakat untuk kepentingan keadilan sosial dan ekonomis. Pernyataan ini merupakan petunjuk umum yang salah satu pengejawantahan hukumnya adalah institusi zakat yang diundangkan oleh Nabi sendiri dan siapa-siapa yang berhak menerimanya telah disebutkan secara jelas dalam surat alTawbah ayat 60. Tetapi para fuqaha sepanjang abad pertengahan tidak mempertemukan petunjuk umum al-Qur'an ini dengan institusi zakat. Zakat hanya dipandang sebatas sebagai bentuk dana bantuan untuk fakir miskin. Jika para ahli hukum Islam mempertautkan kedua ayat tersebut, maka sebenarnya mereka akan melihat bahwa institusi zakat pada faktanya merupakan salah cara di mana ajaran umum al-Qur'an tentang keadilan sosio-ekonomis telah diimplemetasikan. Merupakan suatu kewajiban untuk merumuskan legislasi lainnya di samping zakat

${ }^{39}$ Ilyas Supena, "Rekonstruksi Sistematik Epistemologi Ilmu-Ilmu Keislaman dalam Pemikiran Hermeneutika Fazlur Rahman (1919-1988)", Ringkasan Disertasi, Program Pascasarjana UIN Sunan Kalijaga Yogyakarta, 2007, 6-7 
yang akan menempatkan kehidupan ekonomis masyarakat muslim di atas basis Islam yang sebenarnya. ${ }^{40}$

Proses menggeneralisasikan respon spesifik penurunan wahyu al-Qur'an dan menyatakannya sebagai ungkapanungkapan yang memiliki tujuan moral sosial umum sejalan dengan apa yang diistilahkan oleh Kuntowijoyo sebagai proses demistifikasi. Kalau dekodifikasi teks dijabarkan kedalam teks dan islamisasi pengetahuan mengembalikan konteks ke teks, maka demistifikasi hendak menghubungkan teks dengan konteks. Selama ini harus diakui al-Qur'an kehilangan kontaknya dengan kenyataan, dengan realitas, dengan aktualitas, dan dengan kehidupan. Untuk itu gerakan yang diperlukan adalah demistifikasi atau dengan bahasa lain yang ditawarkan Kuntowijoyo adalah pengilmuan Islam bukan Islamisasi ilmu sehingga umat mengenal lingkungan dengan lebih baik, baik lingkungan fisik, sosial, simbolis, maupun lingkungan sejarah. ${ }^{41}$ Dalam kerangka demistifikasi atau pengilmuan Islam inilah proyek paradigma Islam sebenarnya berada. Memandang realitas dengan kacamata al-Qur'an berarti menghadapkan al-Qur'an dengan kenyataan dan kehidupan. Dengan demikian al-Qur'an akan secara nyata dapat menjadi sumber ilmu dalam pengertian untuk melihat gejala-gejala yang ada dan mengkonstruksinya sebagai sebuah pengetahuan ilmiah.

\section{Catatan Akhir}

Ilmu pengetahuan akan mengalami krisis ketika teori-teori yang dibangun tidak dapat lagi menjelaskan fakta-fakta yang ada. Dalam situasi krisis inilah ilmuwan akan melakukan revolusi sehingga melahirkan paradigma baru. Dewasa ini terlihat jelas krisis yang dialami oleh sains modern yang didominasi oleh paradigma berpikir rasional, sehingga dialektika keilmuan hanya bergerak untuk menguji teori (verifikasi) bukan bagaimana menghasilkan satu perspektif baru dari ilmu pengetahuan. Perspektif baru tersebut tercapai bila cara pandang baik terhadap subyek maupun obyek dapat dilampaui. Sebagaimana pendapat

\footnotetext{
40Adnan Amal, (ed.), Metode Alternatif..., 57.

${ }^{41}$ Kuntowijoyo, Islam Sebagai..., 6.
} 
Kant, manusia melihat obyek senantiasa ditentukan oleh kategori-kategori tertentu.

Wahyu al-Qur'an sebagai sumber pokok dari agama Islam dapat menjadi paradigma baru, karena sebagaimana paradigma dalam konsepsi Thomas Kuhn, al-Qur'an dapat dijadikan sebagai suatu konstruksi pengetahuan yang memungkinkan umat Islam memahami realitas sebagaimana al-Qur'an memahaminya. Konstruksi pengetahuan tersebut akan menjadi dasar bagi umat untuk merumuskan desain besar mengenai sistem Islam termasuk sistem ilmu pengetahuannya. Dengan demikian paradigma al-Qur'an tidak hanya berhenti pada kerangka aksiologis tetapi juga dapat berfungsi memberi kerangka epistemologis

Pemikiran untuk menjadikan al-Qur'an tidak hanya sekedar sumber ajaran agama, tetapi juga sumber ilmu pengetahuan karena al-Qur'an dapat menjadi sebuah paradigma, meniscayakan pergeseran dalam ilmu al-Qur'an. Studi al-Qur'an harus mengesampingkan nuansa sakralitas dan ideologisprimordial dan membangun studinya dengan metodologi yang ilmiah. Konstruksi metodologi ilmiah dimulai dengan mengubah cara pandang terhadap wahyu al-Qur'an, tidak hanya sebatas teks suci yang membicarakan pesan-pesan ritual keagamaan, tetapi juga sebagai yang membicarakan realitas aktual. al-Qur'an sebagai obyek kajian studi al-Qur'an ditempatkan dalam hakikat ontologisnya sebagai teks kebahasaan yang terbuka terhadap pemahaman manusia. Posisi ontologis tersebut membawa konsekuensi epistemologis-metodologis yaitu terbukanya studi al-Qur'an terhadap kerangka analisis modern seperti lingusitik, kritik sastra dan analisis historis. Dengan demikian, dialektika studi al-Qur'an tidak hanya berputar pada lingkaran hukumhukum dan doktrin-doktrin keagamaan, tetapi juga dialektika alQur'an sebagai sebuah teks dan masyarakat kekinian sebagai sebuah konteks. Kebenaran tafsir al-Qur'an dapat diuji sejauhmana nilai-nilai tersebut yang dihasilkan sanggup memberikan pencerahan dan transformasi terhadap dinamika sosial-kemanusiaan masyarakat yang dijumpainya. $W a$ al-Läh a lam bi al-sawāb. 


\section{Daftar Pustaka}

Abdullah, M. Amin. “al-Ta'wil al-Ilmi: kearah Perubahan Paradigma Penafsiran Kitab Suci”, dalam al-Jami'ah Journal of Islamic Studies IAIN Sunan Kalijaga Yogyakarta, volume 39, No. 2, (Juli-Desember 2001)

Amal, Taufik Adnan (ed.). 1987. Metode Alternatif Neomodernisme Islam Fazlur Rahman. Bandung: Mizan.

Arief, Syamsuddin. Kisah Intelektual Nashr Hamid Abū Zayd, http://indrayogi.multiply.com/reviews/item/89, diakses 14 Agustus 2010

Dagun, Save. M. 1997. Kamus Besar Ilmu Pengetabuan. Jakarta: Lembaga Pengkajian Kebudayaan Nusantara (LPKN).

Ichwan, Moch Nur. 2003. Meretas Kesarjanaan Kritis al-Qur'an,Teori Hermeneutika Nashr Abü Zayd. Jakarta: Teraju.

Kaelan. 2005. Metode Penelitian Kualitatif bidang Filsafat. Yogyakarta: Penerbit "Paradigma" Yogyakarta.

1998. Filsafat Bahasa, Masalah dan

Perkembangannya. Yogyakarta: Paradigma.

Kuntowijoyo. 2004. Islam Sebagai ilmu, Epistemologi, Metodologi, dan Etika. Bandung: Teraju Mizan.

Meuleman, Johan. 1994. "Pengantar", dalam Nalar Islami dan nalar Modern: Berbagai Tantangan dan Jalan Baru, Mohammed Arkoun; ter. Rahayu S. Hidayat. Jakarta: INIS.

Muhadjir, Noeng. 2006. Filsafat Ilmu, Kualitatif dan Kuantitatif untuk Pengembangan Ilmu dan Penelitian, Edisi III. Yogyakarta: Rake Sarasin.

. 2006. Filsafat Ilmu, Kualitatif dan Kuantitatif untuk Pengembangan Ilmu dan Penelitian. Yogyakarta: Penerbit Rake Sarasin.

Mustaqim, Abdul dan Sahiron Syamsudin (ed.). 2002. Studi alQur'an Kontemporer, Wacana Baru Berbagai Metodologi Tafsir. Yogyakarta: Tiara Wacana.

al-Najdi, 'Abd al-Raḩmān bin Muhammad bin Qāsim al-'Ashim, 1398 H. Majmū'Fatawa Syaykh al-Islām A hmad bin Taymiyyah. tt: tpn.

al-Qaț̣an, Manna'. 1973. Mabāhith fì 'Ulüm al-Qur'ān. Riyadh: Mansyurat al-'Ashr al-Hadis. 
Rolston, Holmes. 1987. Science and Religion, a Critical Survey. New York: Random House.

Russel, Bertrand. 2004. Sejarah Filsafat Barat, ter. Sigit Jatmiko, dkk. Yogyakarta: Pustaka Pelajar.

Soetomo, Greg. 1995. Sains dan Problem Ketuhanan. Yogyakarta: Kanisius.

Supena, Ilyas. 2007. "Rekonstruksi Sistematik Epistemologi Ilmu-Ilmu Keislaman dalam Pemikiran Hermeneutika Fazlur Rahman (1919-1988)", Ringkasan Disertasi. Yogyakarta: Program Pascasarjana UIN Sunan Kalijaga Yogyakarta.

Syahrur, Muhammad. 1990. al-Kitäb wa al-Qur'ān, Qira'ah $M u^{\prime} a s h i r a h$. Damaskus: al-Ahali.

Syihab, M. Quraish. 1999. Membumikan al-Qur'an, Fungsi dan Peran Wabyu dalam Kehidupan Masyarakat, Bandung: Mizan.

al-Zarkasyi, Badr al-Din Muhammad bin 'Abd Allah. 1998. alBurban fi'Ulüm al-Qur'ān. Beyrut: Dār al-Fikr.

Zayd, Nashr Hamid Abu. tt. Mahfüm al-Nash, Dirāsah fì Ulüm alQur'ān, Kairo: al-Hay'ah al-Mishriyyah al-Ammah li al-Kitab - 2001. Tekstualitas al-Qur'an, Kritik terbadap Ulumul Qur'an, ter. Khoiron Nabdliyin. Yogyakarta: LKiS. 